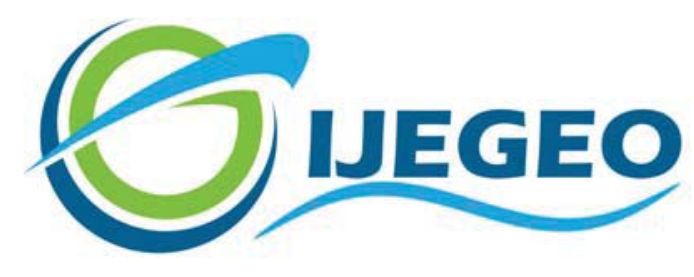

International Journal of Environment and Geoinformatics (IJEGEO) is an international, multidisciplinary, peer reviewed, open access journal.

\title{
Analyzing Effects of Two Different Land Use Datasets on Hydrological Simulations by Using SWAT Model
}

\section{Gokhan CUCEOGLU., Dursun Zafer SEKER., Aysegul TANIK., Izzet OZTURK}

\author{
Chief in Editor \\ Prof. Dr. Cem Gazioğlu \\ Co-Editors \\ Prof. Dr. Dursun Zafer Şeker, Prof. Dr. Şinasi Kaya, \\ Prof. Dr. Ayşegül Tanık and Assist. Prof. Dr. Volkan Demir
}

Editorial Committee (June 2021)

\begin{abstract}
Assoc. Prof. Dr. Abdullah Aksu (TR), Assit. Prof. Dr. Uğur Algancı (TR), Prof. Dr. Bedri Alpar (TR), Assoc. Prof. Dr. Aslı Aslan (US), Prof. Dr. Levent Bat (TR), Prof. Dr. Paul Bates (UK), İrşad Bayırhan (TR), Prof. Dr. Bülent Bayram (TR), Prof. Dr. Luis M. Botana (ES), Prof. Dr. Nuray Çağlar (TR), Prof. Dr. Sukanta Dash (IN), Dr. Soofia T. Elias (UK), Prof. Dr. A. Evren Erginal (TR), Assoc. Prof. Dr. Cüneyt Erenoğlu (TR), Dr. Dieter Fritsch (DE), Prof. Dr. Çiğgem Göksel (TR), Prof.Dr. Lena Halounova (CZ), Prof. Dr. Manik Kalubarme (IN), Dr. Hakan Kaya (TR), Assist. Prof. Dr. Serkan Kükrer (TR), Assoc. Prof. Dr. Maged Marghany (MY), Prof. Dr. Michael Meadows (ZA), Prof. Dr. Nebiye Musaoğlu (TR), Prof. Dr. Masafumi Nakagawa (JP), Prof. Dr. Hasan Özdemir (TR), Prof. Dr. Chryssy Potsiou (GR), Prof. Dr. Erol Sarı (TR), Prof. Dr. Maria Paradiso (IT), Prof. Dr. Petros Patias (GR), Prof. Dr. Elif Sertel (TR), Prof. Dr. Nüket Sivri (TR), Prof. Dr. Füsun Balık Şanlı (TR), Prof. Dr. Uğur Şanlı (TR), Duygu Ülker (TR), Prof. Dr. Seyfettin Taş (TR), Assoc. Prof. Dr. Ömer Suat Taşkın (TR), Assist. Prof. Dr. Tuba Ünsal (TR), Dr. Manousos Valyrakis (UK), Dr. İnese Varna (LV), Dr. Petra Visser (NL), Prof. Dr. Selma Ünlü (TR), Assoc. Prof. Dr. Oral Yağcı (TR), Prof. Dr. Murat Yakar (TR), Assoc. Prof. Dr. İ. Noyan Yılmaz (AU); Assit. Prof. Dr. Sibel Zeki (TR)
\end{abstract}




\title{
Analyzing Effects of Two Different Land Use Datasets on Hydrological Simulations by Using SWAT Model
}

\author{
Gokhan Cuceloglü $^{1 \text {,* iD }}$, Dursun Zafer Seker ${ }^{2}$ iD, Aysegul Tanik $^{1}$ iD , Izzet Ozturk $^{1}$ iD \\ ${ }^{1}$ Istanbul Technical University, Faculty of Civil Engineering, Department of Environmental Engineering, Istanbul, Turkey \\ ${ }^{2}$ Istanbul Technical University, Faculty of Civil Engineering, Department of Geomatics Engineering, Istanbul, Turkey \\ * Corresponding author: G. Cuceloglu \\ * E-mail: cuceloglu@itu.edu.tr \\ Received 19 Sept 2020 \\ Accepted 12 Dec.. 2020
}

How to cite: Cuceloglu, G. et al. (2021). Analyzing Effects of Two Different Land Use Datasets on Hydrological Simulations by Using SWAT Model. International Journal of Environment and Geoinformatics (IJEGEO), 8(2):172-185. doi. 10.30897/ijegeo.828112

\begin{abstract}
Land use/cover (LULC) dataset can be addressed as one of the significant factors governing watershed hydrology. Thus, there is a necessity for using appropriate LULC data especially while working on the hydrology of sensitive watersheds from which drinking water is provided. The aim of this study is to analyze the effect of using two different LULC datasets on the hydrological components of a basin in Turkey. Omerli Basin that covers one of the important drinking water reservoirs of Istanbul with a drainage area of 621 $\mathrm{km}^{2}$ is selected as the study area. The Soil and Water Assessment Tool (SWAT), a physically-based hydrological and public domain model, is used as the hydrological model to evaluate the water budget of the basin. SWAT model is calibrated with an automatic calibration and uncertainty analysis program (SWAT-CUP) by using SUFI-2 algorithm. Model setup is conducted for two different LULC datasets which are CORINE obtained for year 2006, and LULC data produced from 2006 dated LANDSAT 7 ETM satellite image. This pioneer study evaluates and compares the impact of CORINE and LANDSAT 7 ETM LULC datasets used in hydrological modeling by using SWAT model at sub-basin level. It revealed that different LULC datasets yielded quite similar results in terms of surface water runoff and actual evapotranspiration in the Omerli Basin; however, different spatial distribution was observed especially in urbanized sub-basins. Despite the coarser land-use classification in LANDSAT 7 ETM data, it enabled the detection of different LULC classification with higher spatial resolution, and thus, different model outputs were achieved especially in the urbanized sub-basins.
\end{abstract}

Keywords: LANDSAT 7 ETM, LULC dataset, Omerli Basin, SWAT, water resource modeling

\section{Introduction}

Land use/cover (LULC) of a basin is one of the key factors affecting watershed hydrology. Evaluation of hydrological responses to different land-use types is highly valuable for an appropriate watershed management as depicted by Yan et al. (2013). Using natural landscapes for either agricultural or urban purposes may disturb the watershed hydrology by changing the rates of hydrological processes such as interception, infiltration, evapotranspiration and groundwater recharge as well as surface runoff (Baker and Miller, 2013). Hydrological models are valuable tools for studying the processes affected by growing urbanization, quantifying the related impacts, making projections of potential changes and designing water management policies (Branger et al., 2013). Building such hydrological models requires a variety of spatial data structures such as topography, rainfall, soil, and LULC data. Land use information can be considered as an essential input used to parameterize the equations influencing the various components of the hydrologic budget such as evaporation, surface runoff and infiltration in rainfall-runoff models. Therefore, accuracy of LULC datasets used to parameterize the system is an important aspect in watershed modelling (Burian et al., 2002). Moreover, LULC information is not solely vital for the hydrology of a watershed; but also plays a critical role in the quality of water resource(s) within the basin (Huang et al., 2013).

Numerous studies have been conducted to investigate the effect of LULC on watershed hydrology by using a variety of hydrological models such as; Hydrological Simulation Program-Fortran (HSPF) (Choi and Deal, 2008), AVGWLF model (Tu, 2009), U.S. Geological Survey's Precipitation Runoff Modeling System (PRMS) (Qi et al., 2009; Van Beusekom et al., 2014), Water Erosion Prediction Project (WEPP) (Maalim et al., 2013), Soil and Water Asssment Tool (SWAT) (Strauch et al., 2013; Zhou et al., 2013; Zhang et al., 2016), Kedirkan (2019) and MIKE-SHE (Liu et al., 2016).

Majority of studies utilizing LULC datasets aimed to investigate the effect of LULC "changes" on water balance and hydrology (Van Roosmalen et al., 2009; Hosseini et al., 2012; Tong et al., 2012; Bieger et al., 2013; Yan et al., 2013; Khoi and Suetsugi, 2014). Some of them specifically emphasized on the effect of LULC "changes" like urbanization, deforestation and expansion of agricultural land (Brown et al., 2005; Jha et al., 2010; He and Hogue, 2012; Carvalho-Santos et al., 2016; Locatelli et al., 2017; Salmoral et al., 2017; Sonnenborg et al., 2017). A few studies directly evaluated the impact 
of LULC dataset on the hydrological modeling (Wegehenkel et al., 2006; Chormanski et al., 2008; Huang et al., 2013; Branger et al., 2013; El-Sadek and Irvem, 2014; Ahn et al., 2016). Wegehenkel et al. (2006) examined the impact of different spatial LULC datasets (CORINE, LANDSAT, ATKIS and Biotoptypen) on the outputs of a simple conceptual semi-distributed hydrological simulation model THESEUS. Their model results showed only minor impacts on the simulated annual rates of evapotranspiration and groundwater recharge. Chormanski et al. (2008) studied different methods for predicting peak discharges, using a fully distributed rainfall-runoff model (WetSpa) in the Upper Woluwe catchment of Belgium. They derived two different LULC datasets from Ikonos and LANDSAT data, and obtained a minor impact on the estimated peak discharges for less intense rainfall events. Huang et al. (2013) investigated the sensitivity of SWAT model to LULC datasets belonging to different time intervals (2002, 2007 and 2010), and accordingly, they simulated relative differences in predicted monthly stream flow and water quality parameters in a coastal subtropical watershed located in Southeast China. Minor differences in predicted monthly streamflow were detected. ElSadek and Irvem (2014) evaluated the impact of LULC uncertainty on the streamflow and sediment yield in Seyhan River Basin in Turkey by using SWAT model. They used three datasets, namely; CORINE, global land cover characterization (GLCC), and GlobCover. Resultantly, good compliance of model results for different LULC datasets was shown and a minor influence on the simulated monthly stream flows was observed. Moreover, Branger et al. (2013) used five datasets obtained from BDOrtho@IGN aerial images, Quickbird and Spot satellite images by using J2000 model for hydrological simulations. They revealed that using different datasets can induce important changes in the model response; however, these differences may not be necessarily spectacular in terms of total discharges, although more visible for the less urbanized subcatchments. In a study conducted by Ahn et al. (2016), SWAT model was used to simulate the streamflow and water quality predictions were done in an agricultural watershed located in northwestern part of South Korea by utilizing KOMPSAT-2 and LANDSAT datasets belonging to 2004 and 2007. Their simulations showed high uncertainty in streamflow and water quality estimations due to the scale effect from the spatial resolution of different LULC datasets. These studies mostly evaluated the impact of LULC using model outputs for discharge stations used for calibration/validation for the entire basin.

An important contribution is expected from this study regarding the analysis of the effects of two different LULC datasets on the hydrological modeling of a significant basin in Istanbul- Turkey, and the article attempts to give an insight to the modeler on the quantification of the model input uncertainty due to data sources. Omerli Basin is among the most studied basins of Istanbul as it supplies almost $1 / 3$ of the drinking water need of Istanbul Metropolis. Along with rapid population growth within the past few decades in Istanbul, Omerli
Basin has been highly affected by the significant urbanization and industrialization trend (Kaya et al., 2014). Goksel and Turkoglu (1999), Gazioğlu et al., (1998), Yucel et al. (2002), Burak et al., (2002), Goksel et al. (2006), Coskun and Alparslan (2009), Essien et al., (2019) and Kaya et al. (2014) have studied land-use changes in the basin by using different scientific approaches. These studies provided strong evidence that rapid urbanization has been significantly changing the land-use distribution within the basin, and highlighted the utility of technological tools such as Remote Sensing (RS) and Geographical Information Systems (GIS) to monitor these alterations. Several other studies related to the hydrology of the basin were also conducted. Istanbul Water and Sewerage Administration (ISKI) have initially analyzed impacts of climate change, where extreme flows were considered in 2010 (ISKI, 2010). In the recent years, Kara and Yucel (2015) investigated the changes in extreme flows under predicted future climatic conditions by using Hydrologiska Byråns Vattenbalansavdelning (HBV) model. Another work assessed these changes by using 15 different regional climate models using predicted scenarios based on various frequency and intensity of flooding (Kara et al., 2016). Moreover, Cuceloglu and Ozturk (2017) developed a modeling framework by using SWAT and WEAP models for the entire Istanbul Metropolis, and Cuceloglu et al. (2017) modeled the water potential of Istanbul, that also covered Omerli Basin, by using global datasets. The main intention of these studies conducted on Istanbul was to achieve better water management strategies. Recently, SWAT model has been successfully used as a watershed modelling tools in various in Turkey (Cuceloglu and Ozturk, 2017; Kaya and Kutukcu, 2017; Ozcan et al., 2017; Irvem and Sadek, 2018; Jouma and Dadaser-Celik, 2018)

Despite the presence of a variety of studies that put forth valuable contribution to the management of the basin, a study linking the effects of available LULC datasets on the hydrology of the basin was still lacking. Thus, this research is conducted to fill this gap. The main aim of this study was to investigate how LULC data from two different sources (CORINE data obtained for year 2006 and LULC data produced from 2006 dated LANDSAT 7 ETM satellite image by means of supervised classification) affect the hydrology of watershed modeling. SWAT model (Arnold et al. 1998) that is a physically based, hydrological and public domain model was used to simulate the hydrological process in the basin.

\section{Materials and Methods Study Area}

Omerli Basin, which owns one of the important drinking water reservoirs of Istanbul is located on the Asian side of the city with a drainage area of $621 \mathrm{~km}^{2}$. The southwestern part of the basin is considerably under the pressure of rapid urbanization (Coskun and Alparslan, 2009). As of today, population of Istanbul is approximately 18 million; and thus, it demands approximately $3.000 .000 \mathrm{~m}^{3}$ daily freshwater of which 
$95 \%$ is supplied from surface water resources (Cuceloglu and Ozturk, 2017). Omerli Reservoir in the Basin has a reservoir capacity of 397 million $\mathrm{m}^{3}$. The geographical location of the study area and its corresponding topography, river network, discharge station and meteorological stations are shown in Figure 1. The basin is characterized by a transitional climate as it is surrounded by the Black Sea, Sea of Marmara, and
Aegean Sea (Kara and Yucel, 2015). It receives an average annual long-term precipitation of $740 \mathrm{~mm}$ (1960- 2013 period) according to the recordings of the two meteorological stations established in the vicinity of the basin (17610 \& 17638) (Figure 1). Altitude of the basin varies between $18-523 \mathrm{~m}$; comparatively, less urbanized part of the basin is the eastern side that has higher elevation.

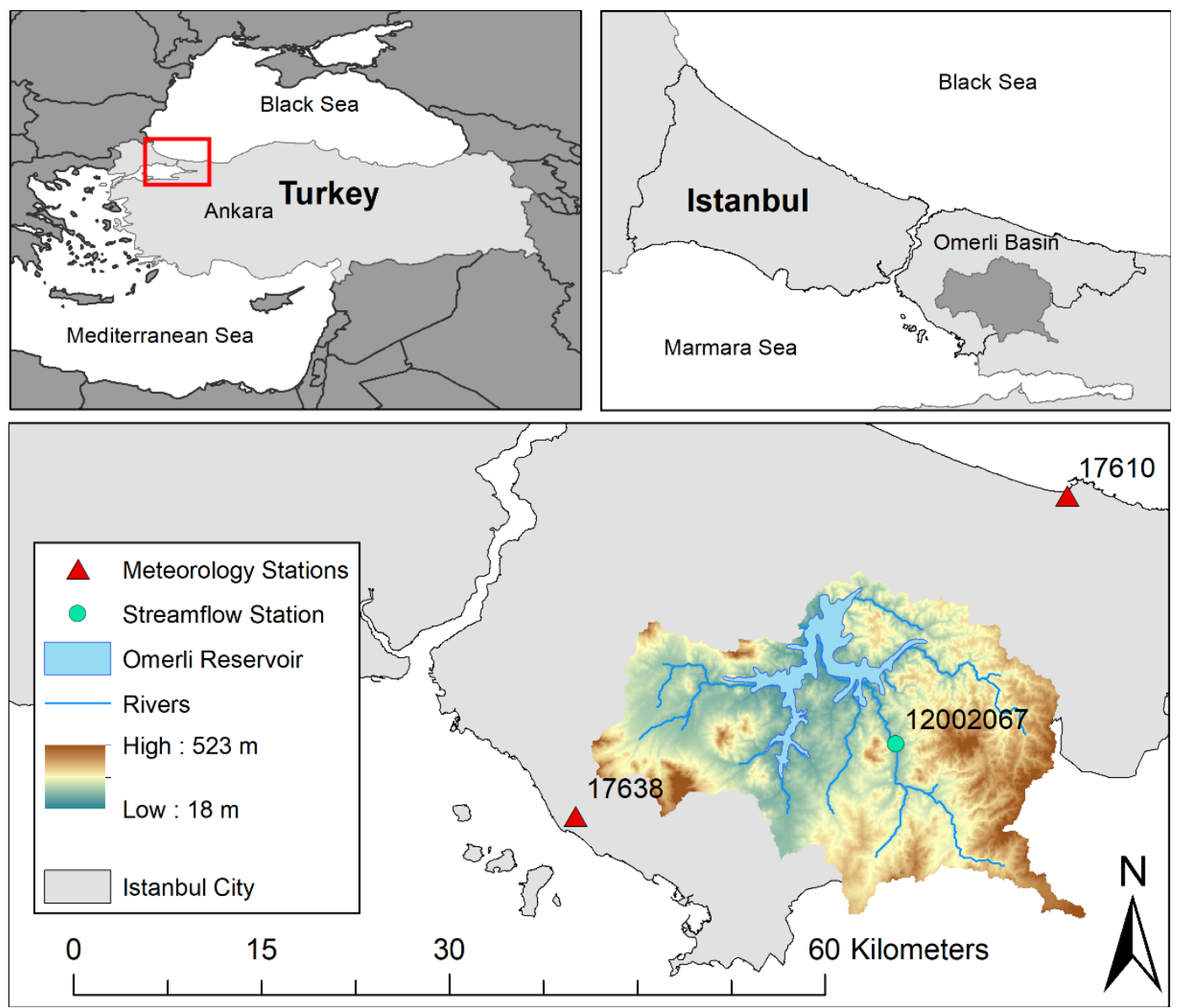

Fig. 1 Geographical location of Omerli Basin in Istanbul

\section{LULC datasets}

LULC is the physical substance covering the Earth's surface like forests, water and grasslands, and LULC types through various classification methods were developed in the field of RS. In this study, two different LULC datasets were compiled to run SWAT model; namely; CORINE and LANDSAT 7 ETM.

CORINE (Coordination of Information on the Environment) is a program put into practice by European Union to ensure economic development, and improve environmental and natural resource management policies in 1985 with the reference year 1990. CORINE dataset is generated by European Environment Agency (EEA) for Europe and is open data. LULC classification of CORINE is divided into 5 main categories at the 1 st level, 15 sub-categories at the 2 nd and 44 sub-categories at the 3 rd level. It has a variety of applications such as policies in environment, agriculture, spatial planning and transportation. It is one of the major land management projects under the Global Monitoring for the Environment and Security (GMES) Project. European
Environmental Information and Observation Network (EIONET) has been established by EEA with the decision of the European Council and got the responsibility of producing and updating the CORINE databases. Currently, Turkey has fully completed the National Land Cover classes according to CORINE classification for 1990, 2000, 2006, 2012 and 2018. SPOT 4 and IRS-P6 satellite images with $20 \mathrm{~m}$ resolution was used in 2006 classification.

The other LULC dataset was obtained from LANDSAT 7 ETM satellite imagery for 2006. Different methods for classifying LULC were developed through the LANDSAT 7 ETM program running for over 4 decades. Development of these methods largely attributed to the improvements in LANDSAT 7 ETM imageries, advancement of computer technology, development of Geographic Information Systems (GIS), and to LANDSAT 7 ETM free access policy. Launching new satellites with high spatial, spectral, temporal and radiometric resolution, and increasing knowledge in the field of information technology were the major 
advancements in the development of contemporary LULC classification methods. Introduction of numericbased pattern recognition algorithms was a major breakthrough in LULC classification, and thus, it forms the basis of modern classification methods. Development of LULC such as pixel-based, knowledge-based, objectbased and many other classification algorithms have been developed in the past few decades. LANDSAT MSS, TM, ETM+ and OLI have so far been used in LULC classification using different methods.

Unsupervised ISODATA classification, a well-known pixel-based classification method, was applied to satellite imagery of Istanbul to produce the LULC. Study region was extracted from this classified image oh Istanbul. Prior to this process, radiometric and geometric corrections were applied to the satellite image. Radiometric correction operation was carried out to reduce the atmospheric effects that occur during the acquisition of the satellite image and to adjust the pixel brightness values. After this pre-processing step, geometric correction process was applied by using appropriate ground control points to define the image in a specified coordinate system and place it on a projection plane, and to eliminate geometric distortions. The ground control points were selected from locations that can be clearly identified on the image and distributed as homogeneously as possible. Pixel based classification process based on the statistical analysis of the pixels was applied so that the information of the LULC can be obtained by means of the image. Satellite imageries are geometrically corrected using the polynomial transformation process and the Universal Transverse Mercator (UTM) projection system. For the accuracy assessment of the classification process, a variety of data such as aerial photographs, orthophoto maps, and 1:25000 scaled standard topographic maps belonging to 2006 obtained from different sources have been used. Overall accuracy has been calculated around $85 \%$, which is generally accepted as sufficiently accurate for the medium-scale satellite imagery.

\section{Model Description}

The Soil and Water Assessment Tool (SWAT) model requires high amounts of input data; however, its various advantages like freely available, open source, well documented and commonly applied all around the world make this model to be used in developing countries.

It is a deterministic continuous-time and semi-distributed hydrological model for application at the basin scale

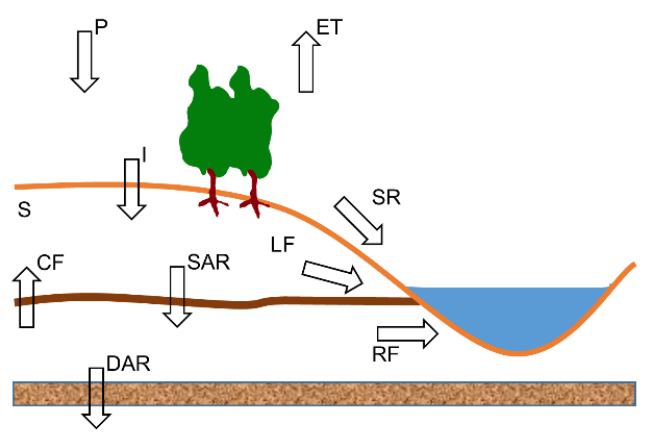

(Kyrsonova and Srinivasan, 2014). It was developed to quantify the impacts of land management practices on surface waters by simulating runoff, infiltration, evapotranspiration, percolation, erosion, plant growth as well as nutrient loads in catchments (Neitsch et al., 2011). SWAT requires spatially distributed data on topography, LULC, soils, land management and climate data. It divides the basin into a number of sub-basins based on topography, and each sub-basin is further divided into hydrologic response units (HRUs) which are unique combination of soil, land-use, slope and land management (Neitsch et al. 2011). In the model, hydrological balances for each HRUs are calculated by using the following equation:

$$
\begin{aligned}
& S W_{t}=S W_{0}+\sum_{t=1}^{t}\left(R_{\text {day }}-Q_{\text {surf }}-E_{a}-w_{\text {seep }}-Q_{g w}\right) \\
& \text { where }
\end{aligned}
$$

$\mathrm{SW}_{\mathrm{t}}$ is the soil water content at time $\mathrm{t}\left(\mathrm{mm} \cdot \mathrm{H}_{2} \mathrm{O}\right), \mathrm{R}_{\text {day }}$ is the precipitation on day $\mathrm{i}, \mathrm{Q}_{\text {surf }}$ is the surface runoff on day $\mathrm{i}\left(\mathrm{mm} \cdot \mathrm{H}_{2} \mathrm{O}\right), \mathrm{E}_{\mathrm{a}}$ is the evapotranspiration on day $\mathrm{i}$, $\left(\mathrm{mm} \cdot \mathrm{H}_{2} \mathrm{O}\right), \mathrm{w}_{\text {seep }}$ is the amount of seepage to the vadose zone from soil profile on day $\mathrm{i}\left(\mathrm{mm} \cdot \mathrm{H}_{2} \mathrm{O}\right), \mathrm{Q}_{\mathrm{gw}}$ is the amount of return flow on day i $\left(\mathrm{mm} \cdot \mathrm{H}_{2} \mathrm{O}\right)$, and $\mathrm{SW}_{0}$ is the initial soil water content. Schematic presentation of the hydrological elements simulated by SWAT is given in Figure 2.

SWAT setup was built with the interface ArcSWAT2012 on ArcGIS 10.3 Desktop version (SWAT2012 rev. 664). Digital elevation map (DEM) provided by the NASA Shuttle Radar Topographic Mission (SRTM) at $90 \mathrm{~m}$ resolution from the Consultative Group for International Agricultural Research (CGIAR) was used to delineate the watershed and its stream network. Soil data was obtained from FAO/UNESCO Soil Map of the World (FAO, 2003). Model setup was conducted for the two LULC datasets; CORINE and LANDSAT 7 ETM for year 2006. Both datasets and resultant classes used are presented in Figure 3. CORINE dataset covers more land use classes than the LANDSAT 7 ETM dataset; CORINE has 13, whereas LANDSAT 7 ETM has 7 classes. LULC types in each dataset and corresponding SWAT LULC type used in modeling are given in Table 1 and Table 2 to provide detailed description on the two different datasets used during model simulation. The local climate dataset is obtained from the Turkish State Meteorological Service (MGM).

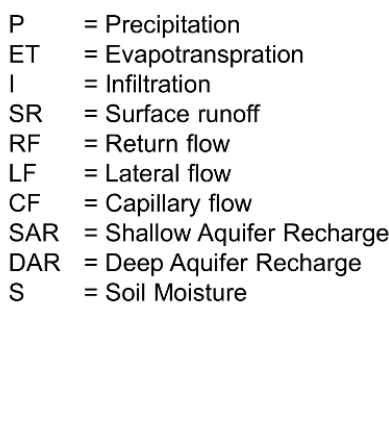

Fig. 2 Schematic presentation of the hydrological cycle elements in SWAT (adapted from Cuceloglu et al. (2017)

Table 1. CORINE land use classes and the corresponding SWAT Code used in the study 


\begin{tabular}{lllll}
\hline CLC Code & Type (level I) & Type (level II) & $\begin{array}{l}\text { SWAT } \\
\text { Code }\end{array}$ & $\begin{array}{l}\text { (\%) of the } \\
\text { basin }\end{array}$ \\
\hline 1 & & & URHD & 5.74 \\
2 & & Continuous urban fabric & URMD & 3.16 \\
3 & Artificial & Discontinuous urban fabric & UIDU & 2.14 \\
6 & surfaces & Industrial or commercial units & UTRN & 0.19 \\
10 & & Airports & URLD & 0.80 \\
\hline 12 & & Green urban areas & AGRC & 8.32 \\
20 & Agricultural & Non-irrigated arable land & Complex cultivation patterns & AGRL \\
21 & areas & Land principally occupied by agriculture, with significant areas & AGRR & 6.43 \\
& & of natural vegetation & & \\
\hline 23 & & Broad-leaved forest & FRSE & 31.06 \\
24 & Forest and semi & Coniferous forest & FRSD & 4.17 \\
25 & natural & Mixed forest & FRST & 17.51 \\
26 & & Natural grasslands & RNGE & 9.32 \\
\hline 41 & Water bodies & Water bodies & WATR & 3.22 \\
\hline
\end{tabular}

Table 2. LANDSAT 7 ETM land use classes and the corresponding SWAT Code used in the study

\begin{tabular}{llll}
\hline LULC Code & Type (level I) & SWAT Code & $(\%)$ of the basin \\
\hline 1 & Water bodies & WATR & 2.30 \\
2 & Forest & FRSE & 38.90 \\
3 & Urban & URHD & 15.95 \\
4 & Cloud & URLD & 0.75 \\
5 & Agriculture & AGRL & 3.45 \\
6 & Semi natural & RNGE & 38.15 \\
7 & Shadow-road & UTRN & 0.50 \\
\hline
\end{tabular}

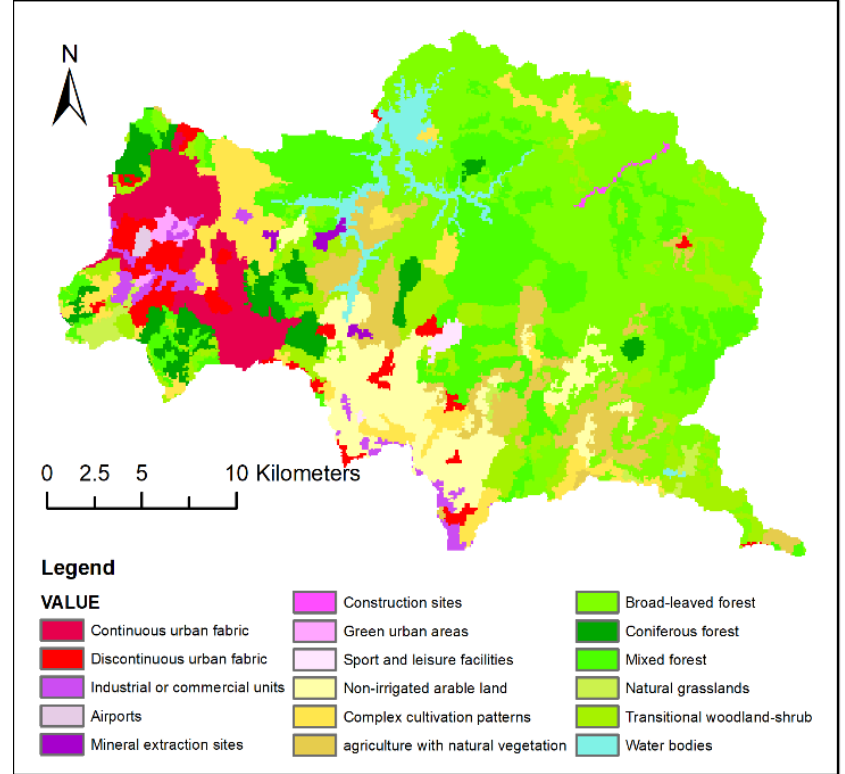

(a)

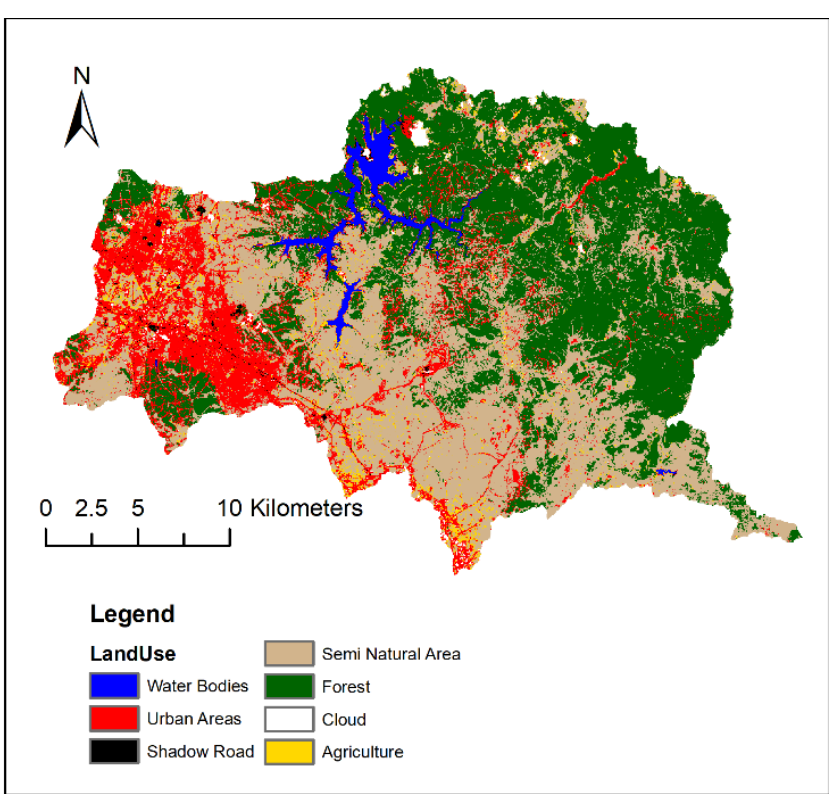

(b)

Fig. 3 LUCL dataset used in this study (a) CORINE 2006 data (b) Classified LANDSAT 7 ETM 2006 image

\section{Model Setup and Parameterization}

Model setup for Omerli Basin was configured with 28 sub-basins (Figure 4), which were further discretized into 525 and 418 HRUs for CORINE and LANDSAT 7 ETM datasets, respectively. Based on the detailed classification of CORINE dataset (Table 1, Figure 3), model constructed by this LULC dataset yielded more HRUs.

Model simulations were performed for 19 years (19952013). First 5 years of simulation was selected as a warm-up period. SCS curve number method (USDA Soil Conservation Service 1972) was used for estimating surface runoff and the Hargreaves method (Hargreaves et al., 1985) for potential evapotranspiration. SWATCUP program was used for calibration/validation of the model with uncertainty analysis using SUFI-2 algorithm (Abbaspour et al., 2004; Abbaspour et al., 2007) during 2000-2013 period. Nash-Sutcliffe efficiency (NSE) was used as objective function (Nash and Sutcliffe, 1970). Commonly used six sensitive SWAT parameters were selected for model calibration (Güngör and Göncü, 2013; Abbaspour et al., 2015). These parameters were CN2, GWQMN, GW_REVAP, SOL_AWC, REVAPMN and ESCO which are expressed as SCS runoff curve number, threshold depth of water in the shallow aquifer required 
for return flow to occur ( $\mathrm{mm})$, groundwater 'revap' coefficient, available water capacity of the soil layer, threshold depth of water in the shallow aquifer for 'revap' to occur (mm) and soil evaporation compensation factor, respectively. Only one flowrate station was available in the basin to obtain the streamflow data. Monthly flowrate time series in gauge station (12002067) seen in Figure 4 was obtained from the State Hydraulic Works (DSI). Same model setup was built for both LULC datasets.

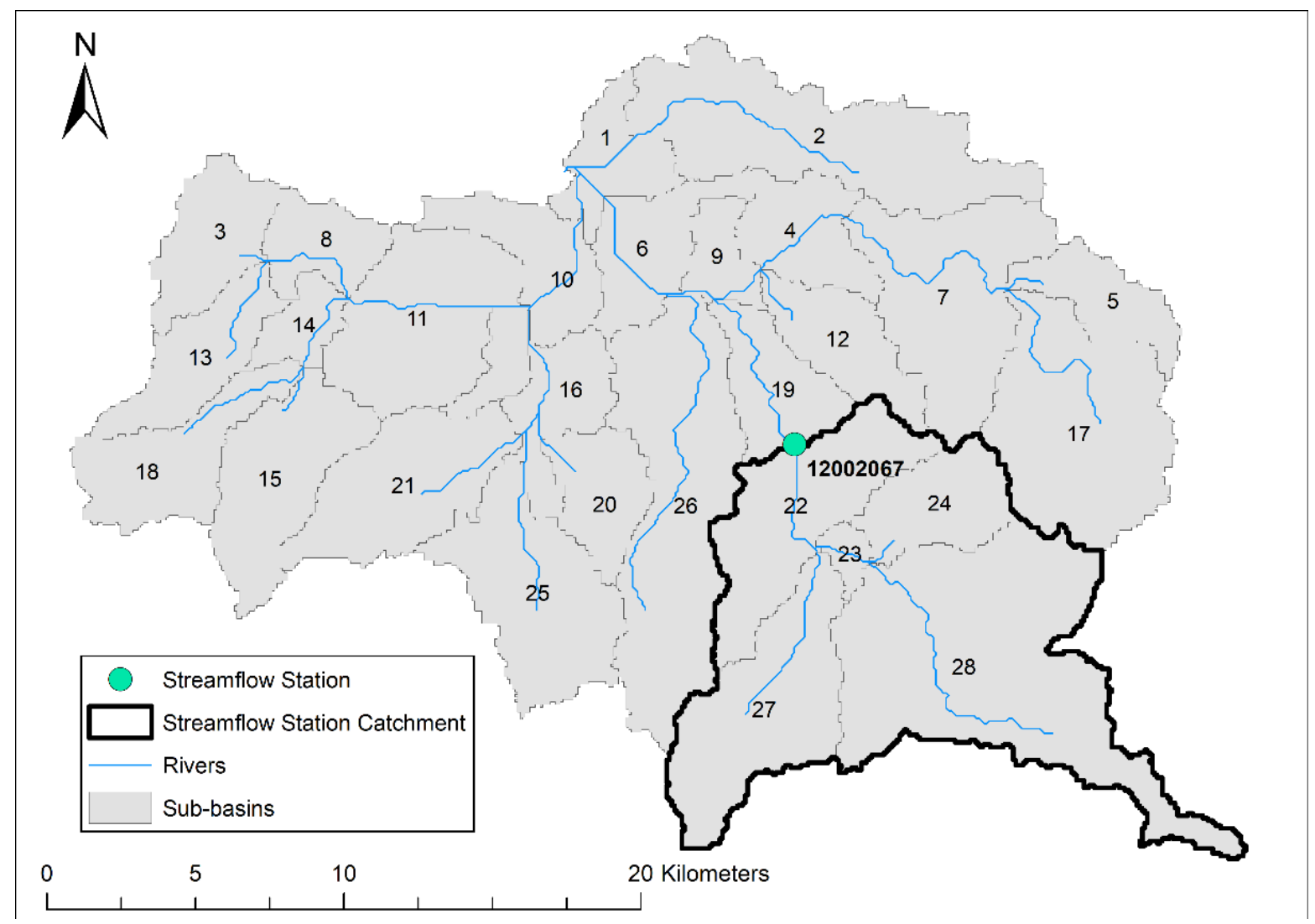

Fig. 4 Model setup for sub-basins of, location of streamflow stations

\section{Results and Discussion}

\section{Sensitivity Analysis of SWAT parameters}

CN2 parameter was found as the most sensitive parameter in this modelling (Table 3). It is followed by the SOL_AWC and GWQMN parameters, which have relative importance on model calibration. Ranking of parameters that are sensitive to surface runoff for both of the datasets was the same. In addition, the final range of parameters used for both datasets were quite similar (Table 3). Possible explanation of this finding is that both LULC datasets have mostly the same classes for the majority of the streamflow stations including sub-basins 22-24, 27 and 28 (Figure 4). These sub-basins were mainly covered by semi natural land and forestry.

Table 3. List of SWAT parameters, their range used for calibration/validation and fitted values

\begin{tabular}{|c|c|c|c|c|c|c|}
\hline LULC data set & Parameter Name $^{1}$ & Initial Range & Final Range & $\begin{array}{c}\text { Fitted } \\
\text { Values }\end{array}$ & t-value ${ }^{2}$ & p-value ${ }^{3}$ \\
\hline \multirow{6}{*}{ CORINE } & r__CN2.mgt & {$[-0.50-0.50]$} & {$[-0.20-0.38]$} & 0.089 & -14.44 & 0 \\
\hline & r__GWQMN.gw & {$[-0.50-0.50]$} & {$[-0.84-0.05]$} & -0.395 & -2.62 & 0.0088 \\
\hline & r_GW_REVAP.gw & {$[-0.50-0.50]$} & {$[-0.76-0.07]$} & -0.343 & 1.38 & 0.1655 \\
\hline & r__SOL_AWC().sol & {$[-0.50-0.50]$} & {$[-0.18-0.43]$} & 0.124 & -3.18 & 0.0015 \\
\hline & r_REVAPMN.gw & {$[-0.50-0.50]$} & {$[-0.24-0.26]$} & 0.011 & -0.45 & 0.6514 \\
\hline & r_ESCO.hru & {$[-0.20-0.20]$} & {$[-0.08-0.13]$} & 0.022 & -0.34 & 0.7285 \\
\hline \multirow{6}{*}{$\begin{array}{l}\text { LANDSAT } 7 \\
\text { ETM }\end{array}$} & $\mathrm{r} \_\mathrm{CN} 2 . \mathrm{mgt}$ & {$[-0.50-0.50]$} & {$[-0.19-0.42]$} & 0.118 & -14.81 & 0 \\
\hline & r__GWQMN.gw & {$[-0.50-0.50]$} & {$[-0.87-0.04]$} & -0.416 & -2.76 & 0.0059 \\
\hline & r_GW_REVAP.gw & {$[-0.50-0.50]$} & {$[-0.82-0.05]$} & -0.382 & 1.08 & 0.2788 \\
\hline & r__SOL_AWC().sol & {$[-0.50-0.50]$} & {$[-0.35-0.21]$} & -0.068 & -4.84 & 0.0000017 \\
\hline & r_REVAPMN.gw & {$[-0.50-0.50]$} & {$[-0.22-0.32]$} & 0.049 & -0.95 & 0.3406 \\
\hline & r__ESCO.hru & {$[-0.20-0.20]$} & {$[-0.06-0.20]$} & 0.072 & -0.28 & 0.7792 \\
\hline & $\begin{array}{l}\text { Ir: parameter value } \\
S W A T \text { groundwater } f \\
2 \text {-value shows a mec } \\
{ }^{3} \text { p-value shows the } \\
\text { as sensitive. }\end{array}$ & $\begin{array}{l}\text { by } 1+\text { given } \\
\text { AT soil files, } h \\
\text { sitivity: the lar } \\
\text { of the sensitivit }\end{array}$ & $\begin{array}{l}r \text { (Abbaspour e } \\
\text { VAT hydrologic } \\
\text { alue are more } \\
\text { smaller the } p-v\end{array}$ & he less & AT man & $\begin{array}{l}\text { ent files, gw } \\
\text { ter assigned }\end{array}$ \\
\hline
\end{tabular}




\section{Calibration and uncertainty at discharge stations}

Model performances for both datasets were evaluated due to $\mathrm{R}^{2}$, NSE and PBIAS (percent bias) values (Table 4). The results can be assessed as 'very good' in terms of PBIAS, whereas $\mathrm{R}^{2}$ and NSE values can be considered as 'satisfactory' according to Moriasi et al. (2007). In Table 4, P-factor shows the percent distribution of observed data bracketed by the 95PPU. R-factor presents the width of the 95PPU band (Abbaspour et al., 2007). A value of $>0.7$ for $\mathrm{P}$-factor and $<1.5$ for $\mathrm{R}$-factor is recommended (Abbaspour et al., 2015). Model performance results for the three objective functions $\left(\mathrm{R}^{2}\right.$, NSE, PBIAS) was found as quite similar. CORINE dataset yielded better findings in comparison to LANDSAT 7 ETM dataset regarding P- and R-factors. As such, CORINE dataset captured $64 \%$ of the observed data; whereas, LANDSAT 7 ETM covered $49 \%$ of observed data during model calibration for the given parameter ranges (Table 4).

Although simulation results can be considered as satisfactory based on literature, SWAT underestimated some of the peak discharges in the basin. It is presumed that the main reason for this discrepancy was the possible incorrect measurement of rainfall data. Figure 5 shows the hydrographs of SWAT model for the two LULC datasets with observed data and 95PPU uncertainty prediction band.

Model simulations for both LULC datasets at discharge stations yielded similar hydrographs for calibration/validation period as shown in Figure 5. This was most likely due to defining the same land-use classification in the sub-watershed for each LULC dataset during calibration of SWAT model.

\section{Results of Hydrological Components}

Contrary to the existing studies, model outputs of this study have been depicted and evaluated by considering model parameterization uncertainty. For this purpose, mean value of $95 \%$ prediction uncertainty (95PPU) obtained through 480 simulations through one iteration for the parameters and their ranges shown in Table 3 were given as model outputs.

Table 4. Results of SWAT model for calibration and validation at gauge station (12006027)

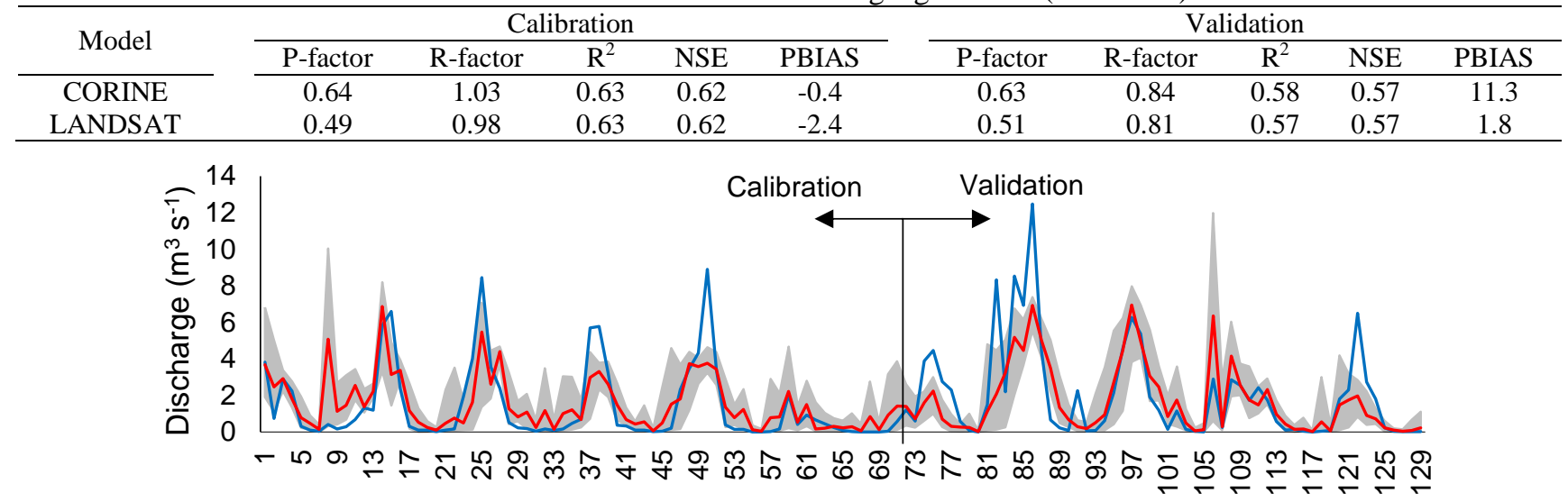

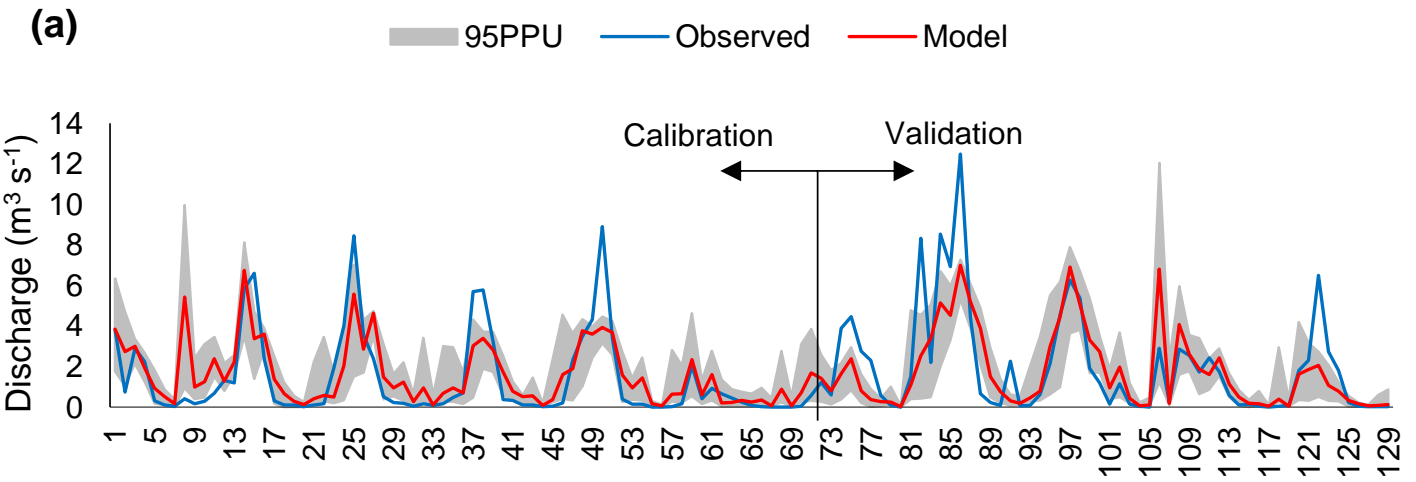

(b)

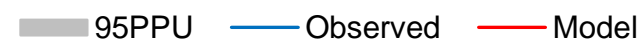

Fig. 5 Hydrographs at discharge stations representing observed data and model simulations, as well as the uncertainty in 95PPU (grey color) outputs of (a) CORINE Model, (b) LANDSAT 7 ETM Model

In Omerli Basin, model simulations showed that difference between two LULC datasets in terms of water yield was about $1.5 \%$, whereas the difference for actual evapotranspiration was $2 \%$ indicating that the two datasets had minor impact over the entire basin. At sub- basin levels, $10 \%$ difference was observed for water yield, and maximum difference was found as $7 \%$ for the actual evapotranspiration. To show the spatial distribution of annual precipitation over the basin and model output for yearly average surface runoff, actual 
evapotranspiration and soil water was mapped at subbasin level (Figure 6) to further illustrate the simulation results at discharge stations and to compare the effects of LUCL datasets on the hydrological components of Omerli Basin. Figure 6a presents the distribution of precipitation for each sub-basin and indicates that higher values of rainfall were observed at the eastern meteorological station than the western one. Model results revealed that the predominant model input affecting the surface runoff yield was the annual precipitation of Omerli Basin during the simulation period, and Figure $6 \mathrm{~b}$ and Figure $6 \mathrm{c}$ suggested that the eastern part of the basin dominated by forests has a higher surface runoff. On the other hand, evapotranspiration was higher in the western part dominated by urbanized land (Figure $6 \mathrm{~d}$ and $6 \mathrm{e}$ ) as significant rainfall differences (almost $300 \mathrm{~mm}$ annually) were observed between the east and the western parts of the basin.

Surface runoff potential of CORINE and LANDSAT 7 ETM LULC outputs varied from 239 to $408 \mathrm{~mm} \mathrm{yr}^{-1}$ and from 244 to $422 \mathrm{~mm} \mathrm{yr}^{-1}$, respectively (Figure $6 \mathrm{~b}$ and $6 c)$. Considering the spatial distribution of the simulated surface runoff, both simulations yielded similar outputs for the north and north-eastern parts of the basin that are in majority covered by forestry (Figure 3). However, runoff responses in southern sub-basins that are under the effect of urbanization exerted different results in the two simulations conducted by different LULC datasets. CORINE estimated greater surface runoff compared to LANDSAT 7 ETM.

Similar to surface runoff, evapotranspiration results for each sub-basin in forestry were almost identical for both simulations. Different evapotranspiration values resulted in the simulations as expected in the southern part of the basin (Figure 6d and 6e). Spatial distribution of soil water content showed similar pattern over the entire basin for both outputs (Figure 6f and $6 g$ ).

In general, surface runoff values were generalized and engaged to the polygons of each sub-basin to evaluate the overall water budget of the basin on annual basis. Therefore, there was no need for mapping more detailed distribution and transitions of runoff.

\section{Discussion of Results}

Model simulations produced almost similar results for agricultural land and forestry regarding surface runoff, actual evapotranspiration and soil moisture components. This study also emphasized on the higher model uncertainty observed in urban areas compared to agricultural land and forestry based on the LULC datasets used (Figure 3).

It is possible to quantify different uncertainties based on data and corresponding resolution. As such, using different LULC datasets may provide valuable information to decrease the uncertainty and to parameterize hydrological/water quality models in the basin. Resolution and quality of the input LULC data used in watershed models may affect the subsequent application of model results in watershed management (Cotter et al., 2003).

CORINE dataset covers more land-use classes than the LANDSAT dataset. CORINE had 13, whereas LANDSAT had 7 classes in Omerli Basin. However, it is possible to represent the basin in 5 classes; such as urban areas, agricultural land, range land, forest area and water bodies. Determination of land-use classes according to SWAT database was almost identical for both datasets that could be the main reason for achieving similar calibration results. Recent case studies reported by Sadek et al. (2014) also maintained similar findings.

$\mathrm{CN} 2$ is one of the most sensitive and therefore, the most commonly used parameter to calibrate the SWAT model as Arnold et al. (2012) depicted. In the sensitivity analysis performed in this study, CN2 was also found to be the most sensitive parameter (Table 3). Likewise, the findings of many other studies refer $\mathrm{CN} 2$ as the most sensitive parameter in SWAT applications (Jan et al., 2010; Strauch et al., 2012; Ashraf Vaghefi et al., 2013; Kushwaha and Jain, 2013; Saha et al., 2014; Qi et al., 2017). Determination of $\mathrm{CN} 2$ parameter is quite important due to its strong correlation with surface runoff and infiltration estimations in basins. Sub-basins $(11,21,25$ and 26) located at the southern part of Omerli Basin demonstrated higher surface runoff values for LANDSAT 7 ETM data in the simulation results. The results were due to the presence of more urbanized land in these sub-basins detected by LANDSAT 7 ETM compared to CORINE dataset.

CN2 was increased by $9 \%$ and $11 \%$ for both datasets (Table 3) after calibration; thus, model yielded even higher surface runoff values compared to default model setup. However, it was not possible to observe the real situation in the basin due to absence of monitoring data for densely urbanized region. It should be kept in mind that the main reason of yielding more surface runoff and higher evapotranspiration rates in forestry was due to spatial distribution of precipitation (Figure 6a) in the Omerli Basin.

Figure 7 is mapped to show a clear image of the difference between of two LULC datasets in terms of surface runoff. However, there was a slight difference between two model simulations using two different LULC datasets. Both model findings yielded quite similar results at the sub-basin, which were subject to urbanization; whereas, the greater difference was observed in the northern part of the basin. Main reason of that situation was that both LULC datasets captured the heavily urbanized areas in the southern part resulting in quite similar findings; on the other hand, they represented different land-use characteristics on the northern part. LANDSAT 7 ETM data had higher spatial resolution compared to CORINE dataset that almost captured semi-natural and urbanized land scattered in the forestry dominating area which was quite representative of the real situation in the basin. Figure 8 shows the Google Earth image of the urbanized land in the northern 
part of the basin. In the absence of field surveys, tools such as Google Earth can be quite useful to detect the urbanized area scattered in forestry in the LULC data. However, such dispersed land were in minority regarding the entire basin; detection and quantification of these areas as LULC input in SWAT yielded different outputs (Figure 8).
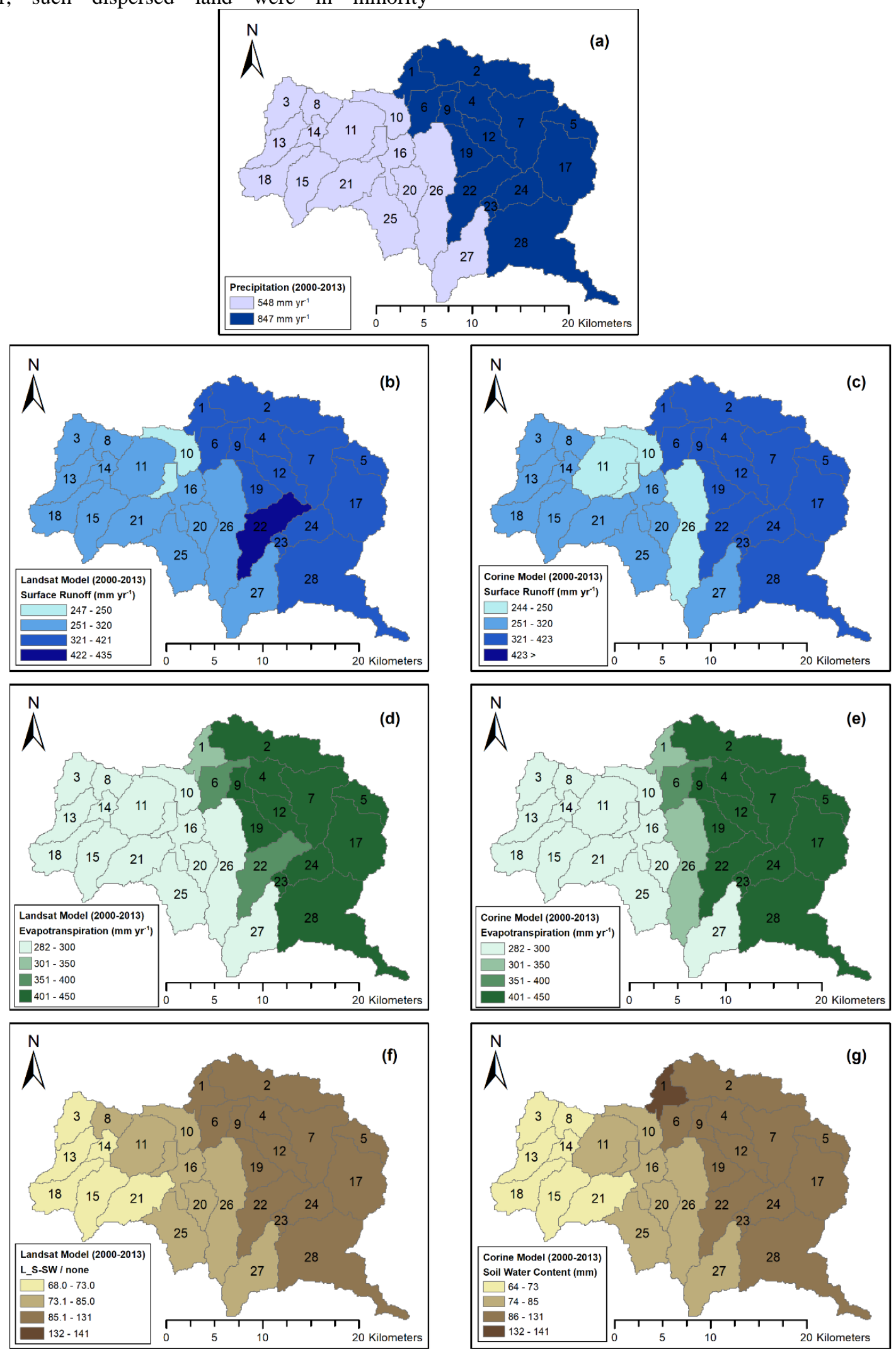

Fig. 6 Spatial distribution of average (2000 and 2013) simulated hydrological components of Omerli Basin at sub-basin level. (a) Average annual rainfall distribution $\left(\mathrm{mm} \mathrm{yr}^{-1}\right)$ (b) LANDSAT 7 ETM results for average annual surface runoff $\left(\mathrm{mm} \mathrm{yr}^{-1}\right)$, (c) CORINE results for surface runoff $\left(\mathrm{mm} \mathrm{yr}^{-1}\right)$, (d) LANDSAT 7 ETM results for evapotranspiration (mm $\left.\mathrm{yr}^{-1}\right)$, (e) CORINE Model results for evapotranspiration ( $\mathrm{mm} \mathrm{yr}^{-1}$ ), (f) LANDSAT 7 ETM results for soil moisture (mm), (g) CORINE results for soil moisture $(\mathrm{mm})$ 
Figure 8 shows the Google Earth image of the basin in 2006 where the settlements, road constructions in the sub-basins were captured as urban areas in LANDSAT 7 ETM dataset, while CORINE represented these subbasins (sub-basins 2, 7, 12, 19) as only forestry or agricultural land (Figure 3). Branger et al. (2013) in the urbanized sub-basins also detected significant impact of image resolution on simulated flow. Subsequently, LULC datasets need to be selected with care based on the depth of the study.

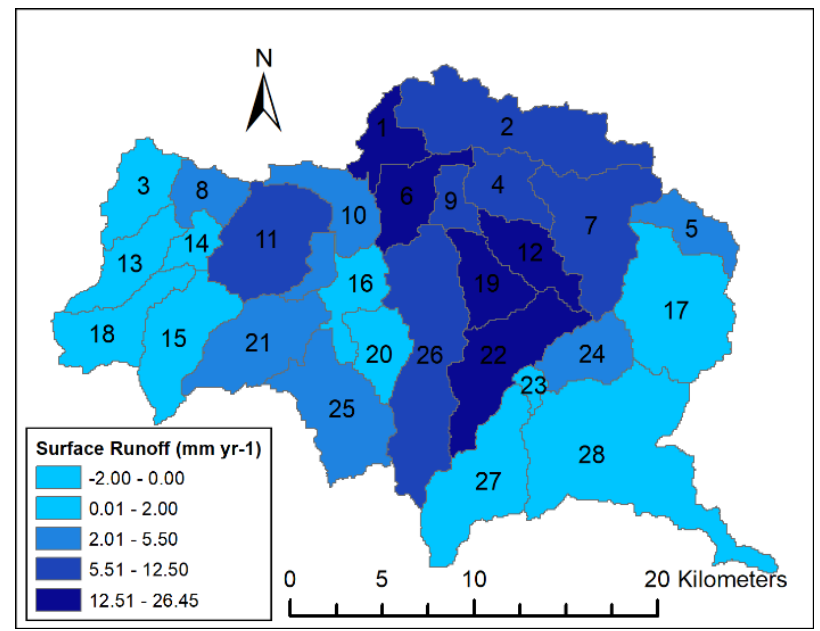

Fig. 7 Difference (LANDSAT 7 ETM model - Corine

Model) map of the annual surface runoff $\left(\mathrm{mm} \mathrm{yr}^{-1}\right)$ calculated based on the simulation period (2010-2013)

Simulation results of urbanized areas mostly located in the western and southern parts of the basin demonstrated similar characteristics due to the similar distribution of land-use classes in contrast to differences attained in forestry dominating land-use. To decrease the model input uncertainty and to improve understanding on the basin dynamics, monitoring streamflow in different landuse types is of utmost important.

On the other hand, it is important to note that estimation of high surface runoff due to different LULC simulation results for Omerli Basin must not be considered that there is higher water potential for the reservoir. The southern part of the basin bears continuous urban fabric, wastewater disposal, and stormwater collection system as well. This system transports considerable amount of rainwater to wastewater treatment plant, and then, the treated effluent is transferred outside the basin via a tunnel. Therefore, quantification of water potential draining into the Omerli Reservoir cannot be estimated by only considering the watershed models. Interpreting model results such as higher surface runoff caused by different LULC datasets derived from watershed models might mislead the local authorities and policy makers as well as the scientific experts. Working on basins like Omerli Basin, which are highly affected by urbanization, requires more data, further analysis, application of infrastructure models, and other tools to aid decision makers, to address water potential studies properly, and to better understand the complex interactions between catchment and in-stream processes in urban systems as stated by Welty et al. (2007) and O'Driscoll et al. (2010).

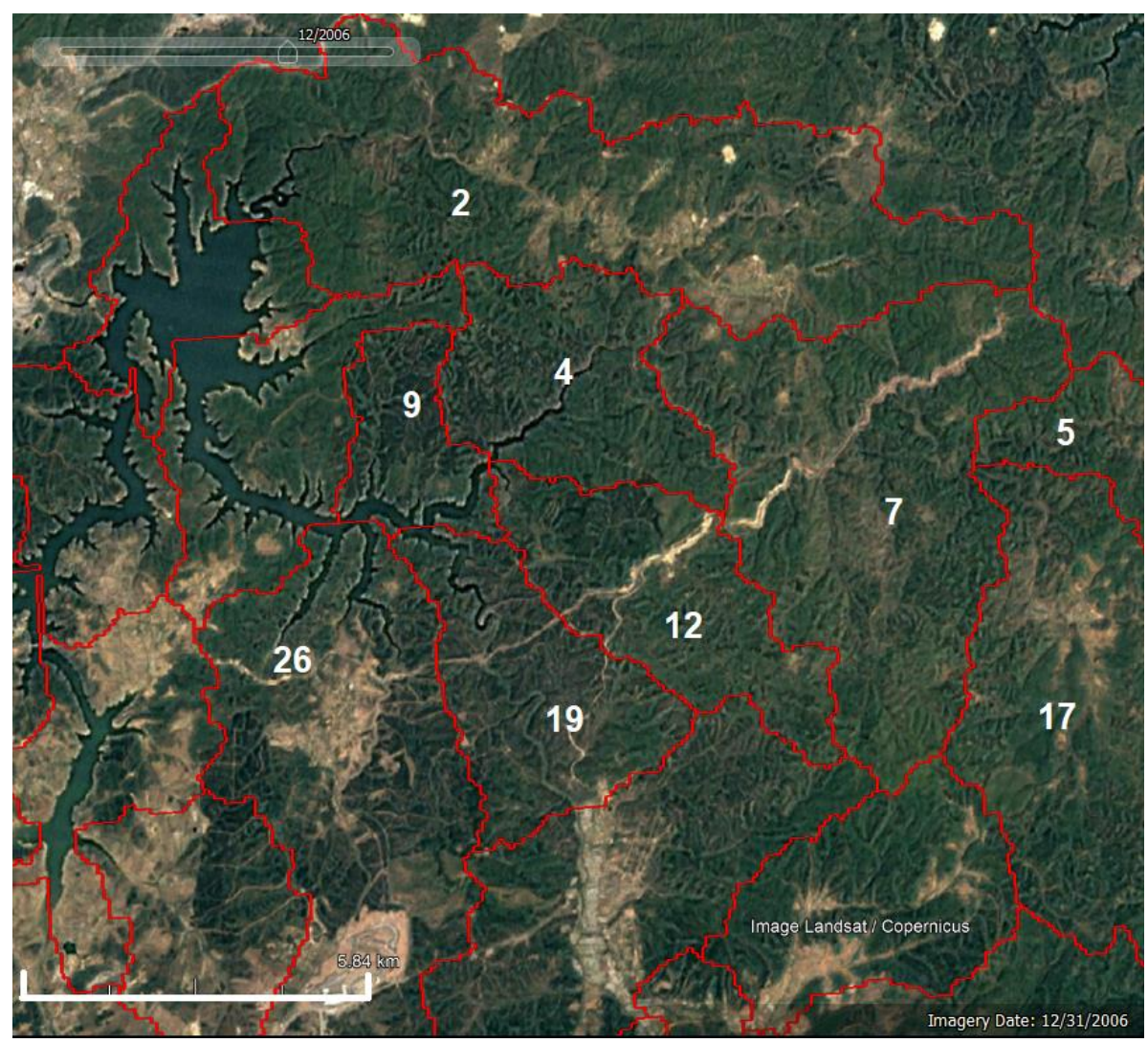

Fig. 8 Google Earth image of the urbanized land in the Southern of the Omerli Basin 
Similar recent studies conducted by Sadek et al. (2014) and Ahn et al. (2016) investigated the effects of using different LULC datasets on hydrological modeling; however, these studies were restricted to limited comparison of LULC datasets for the same period. Branger et al. (2013) also successfully evaluated the influence of land-use data on the water balance components of semi-urban basin. Both Sadek et al. (2014) and Ahn et al. (2016) studied impact of LULC datasets on river flows at basin level. On the contrary, model outputs of this study evaluated different land- uses at sub-basin level, and also considered model parameterization uncertainty using SUFI-2 algorithm. Therefore, this study attempted to fill this gap in literature by comparing effects of CORINE and LANDSAT 7 ETM datasets obtained for the same year on hydrological modeling by SWAT model for the first time not only at the entire basin scale; but also at subbasin level. Results achieved made an important contribution to current literature by comparing two wellknown LULC databases used in environmental science and engineering discipline.

\section{Conclusion and Recommendations}

This study intended to use two different LULC datasets for assessing hydrological components using the SWAT model. The two approaches for model calibration were conducted independently for the two LULC data sets. As there is no baseline land- use data, the comparison of which land-use is better than the other becomes questionable. However, the only reference point to compare the two different datasets was the flowrates in one gauge station in the basin as the main target of the study was hydrological budget estimation rather than inspecting spatial changes.

Moreover, the model calibration was done at monthly time scale to satisfy the requirements of the study. For example, extreme flow conditions such as floods and droughts can be observed with the monthly model calibrations. However, daily calibration should be more sensitive to the two different LULC datasets, which is recommended for further similar studies.

Quality of data source used in watershed modeling has a vital role in presenting the related characteristics of catchments in the model, quantifying the hydrological components, and reducing uncertainty in model input data. In that sense, there is a necessity for using an appropriate LULC dataset especially on the sensitive basins from which freshwater is supplied. Regarding model uncertainty, it is important to note that only one gauging station is used for model calibration and validation that represents only 5 sub-basins among 28 . This situation can bring lots of uncertainty to the study where the model performance is tested under different datasets. The number of the gauging stations should be increased for better model calibration and validation in future studies to decrease model parameterization uncertainty.
This study showed that using different LULC datasets had no significant effect on the model calibration in Omerli Basin. This was basically due to the similar landuse classes utilized in both of the datasets for Omerli Basin. However, spatial distribution of hydrological components of the basin especially for surface runoff varied over the basin. Higher model uncertainty could be seen in the sub-basins defined as urbanized land. Classification of urban areas in LULC dataset is quite important because of their substantial effect on the simulation results particularly on surface runoff and actual evapotranspiration.

Freely available CORINE LULC dataset can easily be used for hydrological modeling studies in the absence of local data and limited time. However, using different datasets is strongly recommended if they are available for the modeler. Using different sources of input data is the key factor for addressing proper uncertainty related to model input, and it is vital for interpreting model results.

\section{References}

Abbaspour, K. C., Johnson, C. A., van Genuchten, M. T. (2004). Estimating uncertain flow and transport parameters using a sequential uncertainty fitting procedure. Vadose Zone Journal. 3(4): 1340-1352

Abbaspour, K. C., Rouholahnejad, E., Vaghefi, S., Srinivasan, R., Yang, H., Kløve, B. (2015). A continental-scale hydrology and water quality model for Europe: Calibration and uncertainty of a highresolution large-scale SWAT model. Journal of Hydrology, 524, 733-752.

Abbaspour, K. C., Yang, J., Maximov, I., Siber, R., Bogner, K., Mieleitner, J., ... Srinivasan, R. (2007). Modelling hydrology and water quality in the prealpine/alpine Thur watershed using SWAT. Journal of Hydrology, 333(2-4), 413-430.

Ahn, S. R., Park, J. Y., Lee, J. W., Lee, M. S., Shin, H. J., Kim, S. J. (2016). Comparison of SWAT streamflow and water quality in an agricultural watershed using KOMPSAT-2 and LANDSAT land use information. KSCE Journal of Civil Engineering. 20, 367-375

Arnold, J. G., Moriasi, D. N., Gassman, P. W., Abbaspour, K. C., White, M. J., Srinivasan, R., ... Jha, M. K. (2012). Swat: Model Use, Calibration, and Validation. Asabe, 55(4), 1491-1508.

Arnold, J. G., Srinivasan, R., Muttiah, R. S., Williams, J. R. (1998). Large area hydrologic modeling and assessment part I: Model development. Journal of the American Water Resources Association, 34(1), 7389.

Ashraf Vaghefi, S., Mousavi, S. J., Abbaspour, K. C., Srinivasan, R., Arnold, J. R. (2013). Integration of hydrologic and water allocation models in basin-scale water resources management considering crop pattern and climate change: Karkheh River Basin in Iran. Regional Environmental Change, 15(3), 475-484.

Baker, T. J., Miller, S. N. (2013). Using the Soil and Water Assessment Tool (SWAT) to assess land use 
impact on water resources in an East African watershed. Journal of Hydrology, 486, 100-111.

Bieger, K., Hörmann, G., Fohrer, N. (2013). The impact of land use change in the Xiangxi Catchment (China) on water balance and sediment transport. Regional Environmental Change, 15(3), 485-498.

Branger, F., Kermadi, S., Jacqueminet, C., Michel, K., Labbas, M., Krause, P., ... Braud, I. (2013). Assessment of the influence of land use data on the water balance components of a peri-urban catchment using a distributed modelling approach. Journal of Hydrology. 505, 312-325

Brown, A. E., Zhang, L., McMahon, T. A., Western, A. W., Vertessy, R. A. (2005). A review of paired catchment studies for determining changes in water yield resulting from alterations in vegetation. Journal of Hydrology, 310, 28-61.

Burak, ZS., Doğan, E., Yücel, ZY., Gazioğlu, C. (2002). Havza Yönetminde Temel İlkeler ve İstanbul Örneği, Türkiye' nin Klyl ve Deniz Alanlarl II. Ulusal Konferansi, 335-345.

Burian, S. J., Brown, M. J., McPherson, T. N. (2002). Evaluation of land use/land cover datasets for urban watershed modeling. Water Science and Technology: A Journal of the International Association on Water Pollution Research, 45(9), 269-276.

Carvalho-Santos, C., Sousa-Silva, R., Gonçalves, J., Honrado, J. P. (2016). Ecosystem services and biodiversity conservation under forestation scenarios: options to improve management in the Vez watershed, NW Portugal. Regional Environmental Change, 16(6), 1557-1570.

Choi, W., Deal, B. M. (2008). Assessing hydrological impact of potential land use change through hydrological and land use change modeling for the Kishwaukee River basin (USA). Journal of Environmental Management, 88(4), 1119-1130.

Chormanski, J., Van de Voorde, T., De Roeck, T., Batelaan, O., Canters, F. (2008). Improving Distributed Runoff Prediction in Urbanized Catchments with Remote Sensing based Estimates of Impervious Surface Cover. Sensors. 8(2), 910-932

Coskun, H. G., Alparslan, E. (2009). Environmental modelling of Omerli catchment area in Istanbul, Turkey using remote sensing and GIS techniques. Environmental Monitoring and Assessment, 153(14), 323-332.

Cotter, A.S., Chaubey, I., Costello, T.A., Soerens, T.S., Nelson, M.A. (2003), Water Quality Model Output Uncertainty as Affected by Spatial Resolution Of Input Data1. JAWRA Journal of the American Water Resources Association, 39, 977-986

Cuceloglu, G., Ozturk, I. (2017). Development of a Model Framework for Sustainable Water Management Practices: Case Study for the Megacity Istanbul. In M. Feierabend, O. Novytska, \& V. Bakos (Eds.), The 9th Eastern European Young Water Professionals Conference (pp. 47-54). Budapest.

Cuceloglu, G., Abbaspour, K. C., Ozturk, I. (2017). Assessing the water-resources potential of Istanbul by using a soil and water assessment tool (SWAT) hydrological model. Water (Switzerland), 9(10).
D. N. Moriasi, J. G. Arnold, M. W. Van Liew, R. L. Bingner, R. D. Harmel, T. L. Veith. (2007). Model Evaluation Guidelines for Systematic Quantification of Accuracy in Watershed Simulations. Transactions of the ASABE, 50(3), 885-900.

El-Sadek, A., Irvem, A. (2014). Evaluating the impact of land use uncertainty on the simulated streamflow and sediment yield of the Seyhan River basin using the SWAT model. Turkish Journal of Agriculture and Forestry. 4(38), 515-530

Essien, E., Jesse, E., Igbokwe, J. (2019). Assessment of Water Level in Dadin Kowa Dam Reservoir in Gombe State Nigeria Using Geospatial Techniques, International Journal of Environment and Geoinformatics, $\quad 6(1), \quad 115-130$. doi.10.30897/ijegeo.487885.

Food and Agricultural Organization (FAO). (2003). The Digital Soil Map of the World and Derived soil Properties; CD-ROM, Version 3.5. Food and Agriculture Organization of the United Nations, Land and Water Development Division: Rome, Italy.

Gazioğlu, C., Yücel, Z.Y., Doğan, E. (1998). Uydu Verileri İle İstanbul Boğazı ve Yakın Çevresindeki İçme Suyu Havzalarına Genel Bir Bakış., Büyükşehirlerde atık su yönetimi ve deniz kirlenmesi kontrolu sempozyumu. 18-20 Kasim 1998,

Goksel, C., Turkoglu, H. (1999). The Integration of Satellite Images and GIS for Omerli Water Basin Land use Changes. 19th EARSel Symposium, Remote Sensing in the 21th Century: Economic and Environmental Applications. Valladolid, Spain.

Goksel, C., Musaoglu, N., Gurel, M., Ulugtekin, N., Tanik, A., Seker, D. Z. (2006). Determination of land-use change in an urbanized district of Istanbul via remote sensing analysis. Fresenius Environmental Bulletin, 15(8 A), 798-805.

Güngör, Ö., Göncü, S. (2013). Application of the soil and water assessment tool model on the Lower Porsuk Stream Watershed. Hydrological Processes, 27(3), 453-466.

Hargreaves, G. L., Hargreaves, G. H., Riley, J. P. (1985). Agricultural Benefits for Senegal River Basin. Journal of Irrigation and Drainage Engineering, 111(2), 113-124.

He, M., Hogue, T. S. (2012). Integrating hydrologic modeling and land use projections for evaluation of hydrologic response and regional water supply impacts in semi-arid environments. Environmental Earth Sciences, 65(6), 1671-1685.

Hosseini, M., Ghafouri, A. M., Amin, M., Tabatabaei, M. R., Goodarzi, M., Kolahchi, A. A. (2012). Effects of Land Use Changes on Water Balance in Taleghan Catchment, Iran. J. Agr. Sci. Tech, 14, 1159-1172.

Huang, J., Zhou, P., Zhou, Z., Huang, Y. (2013). Assessing the influence of land use and land cover datasets with different points in time and levels of detail on watershed modeling in the north river watershed, china. International Journal of Environmental Research and Public Health, 10(1), 144-157.

Irvem A., El-Sadek A. (2018). Evaluation of Streamflow Simulation by SWAT Model for the Seyhan River Basin. Çukurova J. Agric. Food Sci. 33(2): 99-110. 
Istanbul Water and Sewerage Administrationon (ISKI). (2010). Climate Change Impacts on Istanbul and Turkey Water Resources Project Final Report. Istanbul.

Jan, J. Q., De Lannoy, G. J. M., Pauwels, V. R. N. (2010). Comparison of spectral and time domain calibration methods for precipitation-discharge processes. Hydrological Processes, 24(8), 10481062.

Jha, M. K., Schilling, K. E., Gassman, P. W., Wolter, C. F. (2010). Targeting land-use change for nitratenitrogen load reductions in an agricultural watershed. Journal of Soil and Water Conservation, 65(6), 342352.

Jouma, N., Çelik F, (2018). Simulation of Irrigation and Reservoir Storage in the Develi Basin (Turkey) using Soil and Water Assessment Tool (SWAT). Süleyman Demirel Üniversitesi Ziraat Fakültesi Dergisi 1. Uluslararasi Tarımsal Yapılar ve Sulama Kongresi. Özel Sayısı:468-476.

Kara, F., Yucel, I. (2015). Climate change effects on extreme flows of water supply area in Istanbul: utility of regional climate models and downscaling method. Environmental Monitoring and Assessment, 187(9).

Kara, F., Yucel, I., Akyurek, Z. (2016). Climate change impacts on extreme precipitation of water supply area in Istanbul: use of ensemble climate modelling and geo-statistical downscaling. Hydrological Sciences Journal, 61(14), 2481-2495.

Kaya, S., Seker, D. Z., Tanik, A. (2014). Temporal Impact Of Urbanization On The Protection Zones Of Two Drinking Water Reservoirs In Istanbul. Fresenius Environmental Bulletin, 23(12), 29842989.

Kaya, Ş., Kutukcu, A. (2017) Investigation Of Morphometric and Hydrological Characteristics of a Water Basin Using Numerical Models, Fresenius Environmental Bulletin, 26(1), 360-368.

Kedirkan, N. (2019). Water surface Changes of Lakes in the Central Rift Valley of Ethiopia. International Journal of Environment and Geoinformatics, 6(3), 264-267.doi. 10.30897/ijegeo.544770

Khoi, D. N., \& Suetsugi, T. (2014). The responses of hydrological processes and sediment yield to land-use and climate change in the Be River Catchment, Vietnam. Hydrological Processes, 28(3), 640-652.

Krysanova, V., Srinivasan, R. (2014). Assessment of climate and land use change impacts with SWAT. Regional Environmental Change. 15, 431-434

Kushwaha, A., Jain, M. K. (2013). Hydrological Simulation in a Forest Dominated Watershed in Himalayan Region using SWAT Model. Water Resources Management, 27(8), 3005-3023.

Liu, J., Liu, T., Bao, A., De Maeyer, P., Feng, X., Miller, S. N., Chen, X. (2016). Assessment of Different Modelling Studies on the Spatial Hydrological Processes in an Arid Alpine Catchment. Water Resources Management, 30(5), 1757-1770.

Locatelli, L., Mark, O., Mikkelsen, P. S., ArnbjergNielsen, K., Deletic, A., Roldin, M., Binning, P. J. (2017). Hydrologic impact of urbanization with extensive stormwater infiltration. Journal of Hydrology, 544, 524-537.
Maalim, F. K., Melesse, A. M., Belmont, P., Gran, K. B. (2013). Modeling the impact of land use changes on runoff and sediment yield in the le sueur watershed, Minnesota using GeoWEPP. Catena, 107, 35-45.

Nash, J. E., Sutcliffe, J. V. (1970). River flow forecasting through conceptual models part I - A discussion of principles. Journal of Hydrology, 10(3), 282-290.

O'Driscoll, M., Clinton, S., Jefferson, A., Manda, A., McMillan, S. (2010). Urbanization Effects on Watershed Hydrology and In-Stream Processes in the Southern United States. Water, 2(3), 605-648.

Ozcan Z., Kentel E., Alp E. (2017). Evaluation of the best management practices in a semi-arid region with high agricultural activity. Agricultural Water Management, 194, 160-171.

Qi, S., Sun, G., Wang, Y., Mcnulty, S. G., Myers, J. A. M. (2009). Stream flow response to climate and land use changes in a coastal watershed in North Carolina. American Society of Agricultural and Biological Engineers, 52(3), 739-749.

Qi, Z., Kang, G., Chu, C., Qiu, Y., Xu, Z., Wang, Y. (2017). Comparison of SWAT and GWLF model simulation performance in humid south and semi-arid north of China. Water (Switzerland), 9(8).

Saha, P. P., Zeleke, K., Hafeez, M. (2014). Streamflow modeling in a fluctuant climate using SWAT: Yass River catchment in southeastern Australia. Environmental Earth Sciences, 71(12), 5241-5254.

Salmoral, G., Willaarts, B. A., Garrido, A., Guse, B. (2017). Fostering integrated land and water management approaches: Evaluating the water footprint of a Mediterranean basin under different agricultural land use scenarios. Land Use Policy, 61, 24-39.

Sonnenborg, T. O., Christiansen, J. R., Pang, B., Bruge, A., Stisen, S., Gundersen, P. (2017). Analyzing the hydrological impact of afforestation and tree species in two catchments with contrasting soil properties using the spatially distributed model MIKE SHE SWET. Agricultural and Forest Meteorology, 239, 118-133.

Strauch, M., Bernhofer, C., Koide, S., Volk, M., Lorz, C., Makeschin, F. (2012). Using precipitation data ensemble for uncertainty analysis in SWAT streamflow simulation. Journal of Hydrology, 414 415, 413-424.

Strauch, M., Lima, J. E. F. W., Volk, M., Lorz, C., Makeschin, F. (2013). The impact of Best Management Practices on simulated streamflow and sediment load in a Central Brazilian catchment. Journal of Environmental Management, 127. S24S36

Tong, S. T. Y., Sun, Y., Ranatunga, T., He, J., Yang, Y. J. (2012). Predicting plausible impacts of sets of climate and land use change scenarios on water resources. Applied Geography, 32(2), 477-489.

Tu, J. (2009). Combined impact of climate and land use changes on streamflow and water quality in eastern Massachusetts, USA. Journal of Hydrology, 379(34), 268-283.

USDA - Soil Conservation Service. (1972). SCS National Engineering Handbook. Section 4, Hydrology. In National Engineering Handbook. 
Van Beusekom, A. E., Hay, L. E., Viger, R. J., Gould, W. a., Collazo, J. a., Henareh Khalyani, A. (2014). The Effects of Changing Land Cover on Streamflow Simulation in Puerto Rico. JAWRA Journal of the American Water Resources Association, 50(6), 15751593.

Van Roosmalen, L., Sonnenborg, T. O., Jensen, K. H. (2009). Impact of climate and land use change on the hydrology of a large-scale agricultural catchment. Water Resources Research, 45(7). W00A15

Wegehenkel, M., Heinrich, U., Uhlemann, S., Dunger, V., Matschullat, J. (2006). The impact of different spatial land cover data sets on the outputs of a hydrological model - a modelling exercise in the Ucker catchment, North-East Germany. Physics and Chemistry of the Earth.

Welty, C., Miller, A. J., Belt, K. T., Smith, J. A., Band, L. E., Groffman, P. M., ... McGuire, M. P. (2007). Design of an environmental field observatory for quantifying the urban water budget. In Cities of the Future towards Integrated Sustainable Water and Landscape (pp. 72-88).

Yan, B., Fang, N. F., Zhang, P. C., Shi, Z. H. (2013). Impacts of land use change on watershed streamflow and sediment yield: An assessment using hydrologic modelling and partial least squares regression. Journal of Hydrology, 484, 26-37.

Yücel, Z.Y. Gazioğlu, C., Doğan, E., Kaya, H. (2002). Uzaktan Alg1lama ve CBS/B ile Ömerli Barajı ve Yakın Çevresinin İzlenmesi, Türkiye'nin Klyı ve Deniz Alanlarl IV Ulusal Konferansı Bildiriler Kitabl.

Zhang, L., Nan, Z., Yu, W., Ge, Y. (2016). Hydrological Responses to Land-Use Change Scenarios under Constant and Changed Climatic Conditions. Environmental Management. 57, 412-431

Zhou, F., Xu, Y., Chen, Y., Xu, C. Y., Gao, Y., Du, J. (2013). Hydrological response to urbanization at different spatio-temporal scales simulated by coupling of CLUE-S and the SWAT model in the Yangtze River Delta region. Journal of Hydrology, 485, 113-125.

Zhou, P., Huang, J., Pontius, R. G., Hong, H. (2016). New insight into the correlations between land use and water quality in a coastal watershed of China: Does point source pollution weaken it? Science of the Total Environment, 543, 591-600. 